\title{
Ainda será a História Mestra da Vida?
}

FERNANDO CATROGA*

\begin{abstract}
Resumo: Através da história dos conceitos, o autor propõe investigar a idéia de história como mestra da vida, desde os seus primórdios com Cícero - historia magistra vitae - até o mundo contemporâneo, quando a História passa por uma crise de sentido, crise que legitima a pergunta pela história como mestra da vida.
\end{abstract}

Abstract: Through the history of concepts, the author proposes to investigate the idea of history as master of life, from its beginnings with Cicero - Historia magistra vitae - to the contemporary world, when History passes by a crisis of meaning, crisis that legitimate the question about History as master of life.

Palavras-chave: História. Historiografia. Teoria da História.

Key words: History. Historiography. Theory of History.

\section{Pressupostos clássicos do preceito historia magistra vitae}

Para muitos estudiosos, mais do que uma fractura, a metafísica grega terá conferido uma maior racionalização ao cariz ahistórico da mentalidade arcaica. $\mathrm{O}$ tempo continuou a ser vivido como uma manifestação fenomenal, que diversifica e degrada, isto é, como uma imagem onticamente pobre do Modelo - o Ser uno, eterno e imóvel. Dito de outro modo: o tempo do universo seria, tão-só, como afirmou Platão no Timeu, a imagem móvel da eternidade, porque identificado com o movimento dos corpos celestes. Pelo que a sua fenomenologia objectivava o mundo visível (mundo de apareceres e de aparências), enquanto o invisível era assimilado à substância eterna, à qual seria inaplicável qualquer expressão que pudesse sugerir mudança.

Só o que era natural tinha o estatuto de eternidade. Se o fabricado pelo homem ainda possuía esta característica - dado que colhia a sua matéria da natureza -, o que resultava da sua praxis e da sua fala (lexis) seria precário, pois expressava a individuali-

* Universidade de Coimbra. 
dade de uma existência que, com tais obras e feitos, se subtraía à eternidade do género, mas que, sem a mediação de práticas anamnésicas, ficaria condenada à finitude e à morte. ${ }^{1}$

Ter presente todos estes argumentos será condição necessária para que não se caia em interpretações anacrónicas, como a de se pensar que - mesmo nos autores que mais se aproximaram do antropocentrismo (os Sofistas, por exemplo) - os gregos (e os romanos) podem ser elevados a uma espécie de precursores do historicismo moderno e, em particular, do seu princípio segundo o qual é o homem quem "faz" a história.

Importa assim sopesar a pertinência, ou não, destas hipóteses: não terão os ideais gregos de verdade (como os de bem e de belo), e a sua correlativa concepção geométrica do cosmos, sido pouco sensíveis a um tipo de reflexão a que, mais tarde, se chamará "filosofia da história", independentemente das ideações sobre os processos de indagar o passado que se encontram nos textos clássicos (Heródoto, Tucídides, Políbio, Cícero)? Sujeita à tikê (destino, fado), mas ameaçada pela hybris (desmesura), a assunção da história como antropodiceia não significaria fazer do tempo dos homens uma obra supra-sensível, logo, com características análogas às do próprio cosmos? Em suma: não seriam estas premissas incompatíveis com o núcleo forte do substancialismo metafísico grego? Responder a estas questões, ainda que de um modo necessariamente sintético, será uma boa base para se debater a questão concernente às semelhanças e às diferenças que terão existido entre esta perspectiva e as ideias que nortearam o aparecimento da história (sobretudo com Heródoto) como género literário.

\section{Narrar o que se viu}

Desde logo se impõe destacar esta nota fundamental: como Aristóteles assinalou, só o geral, o fixo e o necessário poderiam ser objecto de conhecimento (episteme): "Para quem trate de investigar o que é o contingente, resultará evidente que não haja uma ciência do contingente". ${ }^{2}$ Pelo que a história (como historiografia) seria epistemologicamente mais pobre do que a própria poesia, cabendo à filosofia, saber dos saberes, o lugar cimeiro. Isto é, e como escreveu o Estagirita,

ARENDT, Hannah. Between past and present. New York: The Viking Press, 1968.

2 Consultar o livro 11, 8, da Metafísica de Aristóteles. 
não é ofício do poeta narrar o que aconteceu; é, sim, o de representar o que poderia acontecer: o que é possível segundo a verosimilhança e a necessidade. Com efeito, não diferem o historiador e o poeta, por escreverem verso ou prosa (pois que bem poderiam ser postas em verso as obras de Heródoto e nem por isso deixariam de ser história, se fossem em verso o que eram em prosa) - diferem, sim, em que diz um as coisas que sucederam, e outro as que poderiam suceder. Por isso a poesia é algo de mais filosófico e mais sério do que a história, pois refere aquela principalmente o universal, e esta, o particular. Por "referir-se ao universal" entendo eu atribuir a um indivíduo de determinada natureza pensamentos e acções que por liame de necessidade e de verosimilhança, convêm a tal natureza; e ao universal, assim entendido, visa a poesia, ainda que dê nomes aos seus personagens; particular, pelo contrário, é o que fez Alcibíades ou o que lhe aconteceu. ${ }^{3}$

A citação foi longa, mas impunha-se para ilustrar o que atrás se afirmou: na hierarquia dos saberes, mesmo a poesia era superior à história; esta, limitada à descrição do que se move e aparece, só podia emitir a mera opinião (doxa), narrando, portanto, uma colecção de factos particulares, enquanto aquela revelava capacidade para formular juízos mais universais e sem precisar de estabelecer relações miméticas entre a narrativa e a realidade narrada.

Assinalar esta depreciação é fundamental para se entender o elo existente entre a historiografia e a metafísica gregas, começando por lembrar que aquela surgiu sob o signo do olhar e, logo, da percepção. Por exemplo, para Heródoto de Halicarnasso, considerado o "pai da história", as investigações (historie, apodexis) mais credíveis eram as que decorriam da observação directa (opsis), e não tanto das fontes, ou mesmo das informações alheias, aceites como meras notícias que o historiador-investigador devia registar, mas em que não era obrigado a crer. E esta atitude metódica decorria da própria semântica da palavra que a designava.

Com efeito, tal como eidenai (conhecer), também o vocábulo historia deriva de id-, ver, e histor significava, originariamente, testemunha ocular, e, posteriormente, aquele que examina testemunhas e obtém a verdade, através da indagação. Por conseguinte, historein refere-se tanto a testemunhar como a investigar, acepções que se tornarão mais claras a partir desta regra, consignada no GutapatheBrahamana: discutem dois homens, dizendo um "eu viu-o", e o outro "eu ouviu-o". É certo que não se negava valor informativo àquilo que tinha sido ouvido. Porém, ele era supletivo em relação

3 ARISTÓTELES. Poética. Lisboa: Imprensa Nacional/Casa da Moeda, 2000, 1451a, 36; 1451 b, 10. 
ao da vista e requeria uma maior vigilância crítica. De qualquer modo, no privilégio dado à visão radicava o poder que o histor tinha para derimir as controvérsias, capacidade que o elevava ao papel de árbitro, de juiz. Por sua vez, o termo dikê (= justiça) tem por origem (ao contrário de themis, que denota os fundamentos sacrais do direito positivo, a começar pela sua administração no interior do grupo familiar) o radical deik- (mostrar); logo, dikê remetia para justiça, com o sentido de mostrar com autoridade, mostrar o que deve ser; e este significado também se encontra no composto latino iu-dex, em que deik- aparece unido a ius: só o juiz pode dizer ius. ${ }^{4}$

Verifica-se, assim, que as etimologias de histor, juiz-testemunho e de justiça confirmam o relevo dado às evidências da visão. E a sua raiz permite ainda perceber por que é que, para os gregos, este tipo de "histórias" descrevia, dominantemente, o passado recente: especialistas em procedimentos judiciais, o trabalho dos historiadores incidia, sobretudo, na acribia da observação directa, ou, segundo o modelo hipocrático aplicado na arte médica, na depuração do testemunho oral (Tucídides). Frise-se que, na própria organização textual, expressões como "eu vi" não escondem o sujeito da enunciação, isto é, explicitam a intervenção do narrador no seu relato, doando-lhe autoridade e elevando o "eu vi" (ou o "eu digo") a garante de verdade. Também por isso, quando a retrospectiva vai mais longe e trata de tempos mais antigos e, portanto, não vistos, ela acaba por dar guarida (como se nota em Heródoto) a relatos míticos e tradicionais. ${ }^{5}$

Chegados a este ponto, será altura para perguntar se esta historiografia rompeu, por inteiro, com a mitologia (o que parece não ter acontecido com Heródoto), e se o seu modo de contar não terá dependido da passagem da narração oral para a escrita, trânsito que fomentou uma maior racionalidade. É que, enquanto a primeira procurava convencer, suscitando, no ouvinte, o espanto e o sublime, com a escrita, o trabalho de convencimento do leitor tinha de assentar em juízos argumentativos, por mais excepcionais e exemplares que fossem os acontecimentos narrados. Ora, não há dúvida que, a partir dos séculos V e IV a.C., diminuiu a credibilidade do mito e aumentou a crença nas capacidades da razão inquiridora, como se verifica na sofística e, principalmente, no diálogo socráti-

4 ARENDT, op. cit.; MARRAMAO, Giacomo. Poder y secularización. Barcelona: Península, 1989; BENVENISTE, É. Le vocabulaire des instituitions indo-europénnes II: pouvoir, droit, religion. Paris, 1969.

5 CHÂTELET, François. La naissance de l'histoire. Paris: Seuil, 1968. 
co. Será assim importante levantar a hipótese de que, por exemplo, entre Tucídides - com as suas preocupações com a prova (autopsia) - e Heródoto, a diferença não está tanto na circunstância de ambos não procurarem a verdade, mas residir na finalidade dos seus discursos: o "escrever para sempre" (Tucídides) e o escrever para se declamar perante um público (objectivo ainda patente nos textos de Heródoto) põem em acção estratégias diferentes: em Tucídides, a acribia (a conformidade com os factos) excluía os "dizeres" não comprovados; em Heródoto, tentava-se prender a atenção do receptor, contando o que se viu, em ordem a gerar-se prazer através da sugestão da mimesis. ${ }^{6}$

\section{A imutabilidade e a exemplaridade da História}

Como se assinalou, a sensibilidade grega, conquanto não fosse indiferente aos fenómenos da mudança (daí, o "nascimento da história"), tinha uma obsessão pelo imutável. Mesmo o seu pensador mais "dialéctico" (Heraclito), não só buscou um fundamento omnipresente para o devir, como defendeu que o movimento cósmico culminaria, tal como nas cosmogonias míticas, na deflagração universal (ekpyrosis). Por outro lado, não se deve esquecer que, em termos metafísicos, a corrupção era subordinada ao causalismo formal e final, pois, como se sabe, para o grego, importava captar o que permanece, que especifica, dá configuração e determina a finalidade perseguida por aquilo que devém. O fim seria, portanto, a meta a que os entes particulares aspirariam, consumando-a num ciclo finito, indefinidamente repetido e repetível, sempre diferente e sempre igual, num processo em que o omega seria a explicitação necessária do alfa.

Será pertinente perguntar, porém, se a metafísica não tinha como pano de fundo a sobrevivência de concepções míticas acerca do eterno retorno. $\mathrm{E}$, aos que acham excessiva esta tese, importa lembrar que a configuração do tempo como um círculo também se encontra em Aristóteles, para quem, a par da eternidade do universo, "o tempo parece ser o movimento da esfera, porque este movimento é o que mede os outros movimentos e mede também o tempo... e também o tempo parece ser uma espécie de círculo... pelo que dizer que as coisas geradas constituem um círculo, é dizer que há um círculo de tempo".7

6 LOZANO, Jorge. El discurso histórico. Madrid: Alianza Editorial, 1994.

7 ARISTÓTELES. Problemas, XVII, 3916a. 
De acordo com esta ontologia, compreender-se-ão melhor os limites do valor dos acontecimentos narrados pelos historiadores. Sublinhe-se que, para Aristóteles, todas as criaturas vivas, incluindo o homem (pelo menos enquanto género), estavam incluídas numa natureza sempre presente e, por conseguinte, seriam dotadas de imortalidade. 8 Mediante o ciclo repetitivo da vida, a natureza assegurava, "para as coisas que nascem e morrem, o mesmo tipo de eternidade para as coisas que são e não mudam". Todavia, do ponto de vista da praxis e da capacidade comunicativa do homem, este, ao autonomizar-se do determinismo da espécie, afirmava-se como um indivíduo, condição que ditava a sua finitude. Por palavras de Hannah Arendt, que estamos a seguir, "a mortalidade humana repousa no facto de que a vida individual, um bios com uma história de vida identificável do nascimento à morte, emerge da vida biológica, dzoe. Essa vida individual distingue-se de todas as outras coisas pelo curso rectilíneo do seu movimento, que, por assim dizer, secciona transversalmente os movimentos circulares da vida "biológica'". 9 E a praxis veio reforçar esta autonomização.

A especificidade do novo discurso historiográfico terá residido na sensibilidade que este revelou em relação à face concreta da vida humana. De certo modo, ela prolongava o protesto que, desde a construção de monumentos e da transmissão geracional, possibilitada pela oralidade e pela poesia escrita, procurava remediar a inexorável queda no esquecimento das obras e dos feitos dos homens. Daí que a sua temática tenha incidido, principalmente, sobre situações únicas, feitos ou eventos que "interrompem o movimento circular da vida diária, no mesmo sentido em que o bios rectilinear dos mortais interrompe o movimento circular da vida biológica. $\mathrm{O}$ tema da história são essas interrupções - o extraordinário, em outras palavras". Mas, se foi assim, poder-se-á concluir, sem mais, que "os grandes feitos e obras de que são capazes os mortais, e que constituem o tema da narrativa histórica, não são vistos como parte, quer de uma totalidade ou de um processo abrangente", porque "a ênfase recai sempre em situações únicas e rasgos isolados"? 10

Se, com esta afirmação, se pretende sustentar que os gregos não postulavam a existência de qualquer logos imanente aos eventos humanos, que se explicitasse num finalismo sobredeterminado

Ver o tratado Da alma, de Aristóteles, especialmente, 425b13.

9 ARENDT, op. cit.

10 Idem 
pela ideia de futuro, a tese é aceitável. Todavia, convém frisar que o uso da exemplaridade narrada pelos historiadores obedecia a propósitos de convencimento, exigência que levava à inserção dos acontecimentos em totalidades finitas e sem a existência de qualquer pretensa lógica auto-suficiente a comandar a irreversibilidade do devir universal, como será apanágio das futuras "filosofias da história".

Como alguma história da historiografia clássica tem sublinhado, comummente, as "investigações" seleccionavam conjuntos limitados de factos que se sucederam no tempo, mas que só eram explicáveis através de uma ordenação que lhes conferia forma, integrando-os num todo coerente; contra o caos, a narração construía uma totalidade, conquanto finita e fechada, que, tal como na tragédia, era tecida por uma trama com um princípio, um centro e uma conclusão. Deste modo, explica-se que os historiadores gregos (e romanos), mesmo os mais factualistas, não se preocupassem com a descrição dos eventos tal qual eles aconteceram; estes só ganhavam sentido desde que incluídos num enredo. Com isso, e ao invés do que pensou Aristóteles, o discurso historiográfico ultrapassava o particular (as situações únicas e as acções individuais), pois a verdade do narrado não estaria tanto na adequação dos enunciados à realidade, mas mais na sua correlação e correspondência com um modelo de virtudes - pressuposto que muitos, como Plutarco, não deixarão de explorar -, ou com uma teoria, principalmente com aquela que apontava para a existência de oscilações cíclicas nos negócios humanos (Políbio), ou a que pressupunha a identidade da natureza humana (Tucídides). Em síntese: a narração, apesar do seu aparente cariz doxográfico, tinha subjacente um ideal de verdade que era sinónimo de construção de conjuntos harmoniosos, em consonância com o que também se encontrava objectivado no ideal epistémico e estético da Hélade.

\section{A memória e o magistério da história}

É dentro destes parâmetros que aqui se discute a função social que os gregos atribuíam à escrita da história. Esta devia ser bela e pragmática, dado que os ritmos da vida poderiam vir a repetir-se. Mas, enquanto "arte de memória", e protesto contra a mortalidade a que estavam sujeitos os dizeres e as obras humanas, ela também era monumento, isto é, um garante da vitória sobre o esquecimento. E estas funções já se encontram presentes em Heródoto, que, com intenções de imparcialidade, escreveu as suas His- 
tórias "para que os feitos dos homens não desvaneçam com o tempo, nem fiquem sem renome as grandes empresas, realizadas quer pelos Helenos quer pelos Bárbaros".11

Sem ambiguidades, colocava-as sob a tutela de Mnemosyne. Compreende-se. É que, como afirmou um sábio grego, "os homens morrem, porque não são capazes de juntar o começo e o fim"; e só Mnemosyne, a deusa da memória e, consequentemente, a mãe de todas as musas, podia ligar o que os indivíduos foram, com o que são e com o que serão.12 Através da cristalização do que se viu e indagou, possibilitada pela escrita, tentava-se vencer a amnésia a que, entregues a si mesmas, estavam condenados os feitos que marcam a individualidade do homem. A escrita da história propunha-se derrotar a amnésia produzida pela corrupção do tempo, isto é, pela índole não natural das acções especificamente humanas, logo, pela biografia dos indivíduos, concretizada num tempo rectilíneo mas finito, embora mergulhada num tempo cíclico ou eterno, próprio da natureza e do género. Por outras palavras: só a fama, garantida pela memória, poderia vencer a precariedade de tudo o que resultava da praxis, aproximando-se da eternidade das coisas naturais.

Neste horizonte, não espanta a vocação pedagógica (e cívica) da nova literatura historiográfica: ela contava o que já foi, com o fito de lembrar, à luz dos ritmos cíclicos, ou da repetição do que é característico da natureza humana, o que poderá vir a acontecer, mostrando que, não obstante ao homem só ser dada uma pequena margem para fugir ao destino, a tikê não conduziria ao fatalismo absoluto, e o fado, que preside à vida humana, só teria um poder destruidor, porque, tal como se mostrava na tragédia, o homem é habitualmente cego em relação aos seus ditames, não sabendo formular as opiniões correctas que, sem se cair na hybris, permitem evitar os seus golpes decisivos..$^{13}$

O ritmo do cosmos, a raiz ahistórica da natureza humana e a fama (perpetuada pela escrita) são, assim, as traves-mestras que devem ser invocadas para se entender melhor o consabido preceito greco-romano (Tucídides, Políbio, Cícero) segundo o qual a história é mestra da vida (historia magistra vitae): "Historia vero testis temporum, lux veritatis, vita memoriae, magistra vitae, nuntia vetustatis, qua voce alia nisi oratoris immortalitati comendatur".14 A tarefa directora que Cícero adjudicava à história (ou melhor, à história como arte) tinha

11 HERÓDOTO. Histórias. Livro 1. Lisboa: Ed. 70, 1994. 1.1.

12 CATROGA, Fernando. Memória, história e historiografia. Coimbra: Quarteto, 2001.

13 BENAVIDES LUCAS, Manuel. Filosofias de la historiai Madrid: Sínteses, 1994.

14 Ver a De oratore, de Cícero, especialmente: II, c.9, 36 e 12, 51. 
em vista obter efeitos análogos aos da oratória, fornecendo a esta, com imparcialidade, uma colecção de exemplos pedagógicos (plena exemplorum est historia). ${ }^{15}$ Para isso, e tal como outras formas de evitar a queda no esquecimento, a historiografia era também garante de transmissibilidade. $\mathrm{O}$ que dá sentido ao facto de ela ter sido qualificada, não só como verdadeiro testemunho do tempo e como discurso aletológico ("lux veritatis"), mas também como "vita memoriae". No fundo, o escritor romano sublinhava os liames estreitos que enlaçavam estres três níveis, dando expressão aos ensinamentos de Heródoto e ao que já Tucídides escrevera acerca da utilidade da sua História da Guerra do Peloponeso: partindo do pressuposto de que a natureza humana é o grande motor da história, o registo daquele evento seria uma aquisição para sempre, pois a "ideia-tipo" (Raymond Aron) que estruturava a obra continuaria a valer: independentemente dos indivíduos concretos (vivos ou vindouros), a natureza humana permanecerá a mesma. De facto, o seu livro não se limitava a descrever acontecimentos do século $\mathrm{V}$ a. C.; tinha igualmente a finalidade de servir de modelo para a compreensão dos que, no futuro, e em virtude do inalterável carácter humano, virão a ser semelhantes ou análogos.

A cristianização das consciências, com as suas promessas de cariz sotereológico e escatológico, assentes na predominância da fé sobre a razão e, consequentemente, da verdade revelada sobre a inquirida, interiorizou um entendimento providencialista da história justificado à luz da superioridade da Cidade de Deus sobre a Cidade dos Homens (Santo Agostinho). Assim, entende-se que, no plano historiográfico, a concepção greco-romana, segundo a qual a investigação do passado tinha uma função pragmática, recebesse, agora, uma justificação dominantemente metafísico-religiosa. Por isso, também não se dava continuidade ao preceito herodotiano que baseava a validade do narrado no "visto", e mesmo no "ouvido", já que se ousava contar o que ultrapassava esses limites, desde que pudesse ser afiançado pela crença e pela autoridade da Igreja; portanto, o passado só podia ser objecto historiográfico se fosse apreendido através da fé, o que colocava o texto sagrado como exclusivo paradigma de explicação do sentido do tempo. E o pretérito, objecto de fé, contrastava com o presente, objecto de conhecimento. Consequentemente, este horizonte torna compreensível que historiadores cristãos aceitassem, sem vigilância crítica, as narrações fornecidas pela tradição e garantidas por uma autori-

15 KOSELLECK, Reinhart. Futuro pasado: para una semántica de los tiempos históricos. Barcelona: Paidós, 1993. 
dade reconhecida (Igreja, Monarquia, Universidade), ou pela santidade e posição social de quem as transmitia. Esta credulidade levava-os a "falar do passado, referido nesses relatos, como se eles próprios o tivessem vivido". 16

Tais pressupostos ajudam a inteligir as características essenciais que enformaram a historiografia medieval, a saber: a periodização do tempo histórico feita segundo o modelo cristológico; a sua função catequética; a sua ultrapassagem dos particularismos (a unicidade de Deus fundamentava, numa cristianização do velho estoicismo, uma perspectiva universalista de humanidade); a sua escrita, encarada como um trabalho anónimo e geracionalmente contínuo (como tem sido assinalado, não se fazia distinção entre as noções de historiógrafo e de cronógrafo, bem como, quanto aos géneros, entre anais, crónicas, e histórias); a inexistência de uma consciência autoral, característica que explica a índole colectiva de muitos textos historiográficos da época e que relativiza as posteriores acusações de plagiato; e, por fim, a ordenação das idades e acontecimentos de acordo com a justificação providencialista, bem como o seu temário dominantemente apologético e hagiográfico. ${ }^{17}$ Neste contexto, o magistério das narrativas já não visava produzir efeitos de índole ético-cívica; a exemplaridade enaltecida só tinha sentido desde que fosse de conteúdo religioso e se convidasse à imitação das vidas virtuosas, tendo em vista a salvação das almas.

II

\section{A necessidade histórica e a acção dos indivíduos}

Na modernidade, a comparação de pensadores que procuraram teorizar uma nova visão do tempo histórico, como Vico, Voltaire, Lessing, Turgot, Condorcet, Kant, Schiller, Schelling, Hegel e seus continuadores, permite captar, nas suas diferenças, a existência de um conjunto de ideias comuns sobre a estruturação do sentido da evolução humana: a suposição de que este só seria conhecido quando a humanidade fosse perspectivada como uma totalidade em devir; a crença na existência de uma ordem ideal subjacente à história empírica (Vico), ou melhor, na racionalidade do real e na faculdade de a razão a esclarecer, iluminando o aperfeiçoamento humano; o princípio de acordo com o qual a diacronia das sociedades é fruto de antíteses, intrínsecas ao "sujeito-motor" ima-

16 POMIAN, Krzysztof. L'ordre du temps. Paris: Gallimard, 1984.

17 COLlingWOOD, R.G. A ideia de história. Lisboa: Presença, s.d.; GOOCH, Georg. Historia e historiadores en el siglo XIX. México: FCE, 1984. 
nente da história, que se desenrolam de um modo objectivo, universal e necessário; a fé na vocação perfectível e progressiva da humanidade. Por sua vez, todas elas tenderam a descrever esse percurso como um caminhar do Oriente para o Ocidente, viagem apresentada como uma luta para que a história passasse do reino da necessidade para o da liberdade, com um desfecho eurocêntrico. É que a Europa seria não só o lugar da definitiva revelação da verdade, mas também o agente da assunção da história como história universal.

\section{O sentido da inteligibilidade da História}

Para demonstrarem tudo isto, as filosofias da história da modernidade procuraram ultrapassar o entendimento dos fenómenos humanos em termos de explicações mecanicistas, não obstante compartilharem, com os novos cientistas da natureza (a física, sobretudo), uma análoga convicção acerca da inteligibilidade do mundo. Recorde-se que a leitura sub specie machinae só funcionava nos quadros de uma natureza sujeita à repetição e com explicações baseadas na causalidade material e eficiente; logo, despidas de qualquer teleologismo. A natureza (física, animal, humana) ainda não era a resultante de um processo evolutivo (como o será para Lamarck e Darwin), mas era caracterizada em termos de imutabilidade, eternidade e constância. Porém, a história começava a ser valorizada como o resultado da vitória da liberdade contra o "ordenamento mecânico" da natureza, e o homem a ser visto como um ser racional, livre e eminentemente prático. E esta antropologia era fruto da expropriação imanentista do Logos divino inscrito em cada indivíduo, operação bem patente, desde Descartes, nas filosofias do cogito. Assim sendo, entende-se que, para Kant (tal como para Voltaire, Lessing, Turgot, Schiller, Condorcet, Hegel, Marx, Comte, etc.), a história fosse um processo, não só evolutivo, mas também finalístico, verificação que confirma esta hipótese: a historicidade só pôde ser pensada no quadro de uma episteme alicerçada no divórcio entre o sujeito e o mundo físico (iniciado por Descartes e praticado pela ciência moderna) e na subordinação da leitura da natureza à experiência histórica do homem.

Tanto uma posição como outra ajudaram a romper com as representações cíclicas, passando o presente a ser vivido como uma permanente actividade de preenchimento do tempo, praxis em que o homem devia agir "como se" a finalidade ético-racional que a priori ele pode encontrar quando se eleva a uma posição 
transcendental (Kant) - estivesse inscrita na ordem natural das coisas. Mas esta atitude também convidava a que este tipo de teleologismo sofresse uma maior ontologicização, linha já visível na lição de Schiller, subordinada ao tema $O$ que significa e com que fim se estuda história universal (1785), e que o idealismo objectivo alemão e as suas posteriores inversões materialistas acentuarão. ${ }^{18}$

Explica-se agora melhor por que é que a substantivação da humanidade e da história caminhou a par com a entificação da ideia de progresso. Esta última tendeu mesmo a confundir-se com o grande rio da história, fundindo no seu leito correntes distintas, mas que nele convergiam, a saber: a secularização do milenarismo de matriz judaico-cristã; o optimismo epistemológico e histórico, enraizado nas novas ciências e nos seus efeitos sociais; a secularização dos fundamentos da sociedade e do poder, expressa nas diversas teorias do contrato social (Hobbes, Locke, Rousseau, Kant), as quais, ao proporem um modelo de inteligibilidade, fixavam, igualmente, um antes (estado da natureza) e um depois, definido como um campo criado pela determinação da vontade dos homens. E todos estes factores, conjugados com o princípio clássico segundo o qual só há conhecimento do geral, não deixaram de reforçar o fundo prometeico que insuflava a mundividência moderna. É assim lógico que as núpcias entre a ideia de humanidade e a de progresso se tenham selado no reconhecimento da história como uma realidade dinâmica, que arrastava, não uma parte ou faceta, mas o espírito humano como um todo evoluente, devido à sua infinita potencialidade de aperfeiçoamento. ${ }^{19}$

No entanto, a credibilização desta ideia não deixou de operar uma alteração significativa no recurso à velha analogia - e à correspondente tradução metafórica de cariz organicista - que, desde pelo menos Santo Agostinho, passando por Vico, apresentava a periodização do itinerário da humanidade como um trilho similar ao dos seres vivos.Todavia, se esta comparação parecia incontroversa, quando se acreditava que a humanidade era finita - isto é, tinha nascido, crescido, alcançado o seu apogeu, mas estaria decadente e iria morrer -, a ideia de progresso (mesmo quando alguns correctivos menos optimistas lhe são introduzidos) exigia o fomento da crença na sua infinitude e amortalidade.

18 SCHILLER, Friedrich von. Escritos de filosofia de la historia. Murcia: Universidade de Murcia, 1991; MALTER. Rudolf. Schiller como filósofo de la historia: in: SCHILLER, op. cit.

19 MARRAMAO, op. cit.; MOSÈS, Stéphane. L'ange de l'histoire: Rosenzweig, Benjamin, Scholem. Paris: Seuil, 1992. 
Não obstante a pressuposição de uma expectativa aberta e da recusa do encerramento da história (particularmente enfatizada por Kant), ter-se-á sempre de perguntar se a indicação de uma meta futura, caracterizada como "idade", "estádio" ou mesmo como "reino" (Reich) - numa reactualização secularizada da tradição messiânica -, e vista como fruto de um sujeito colectivo (espírito do mundo, espírito da humanidade, luta de classes, luta de raças), e não como o somatório da acção dos indivíduos, também não supunha, aprioristicamente, um focus imaginarius, numa projecção, feita no presente, de um "algures" que envolvia o ordenamento (e o julgamento) do que aconteceu e do que virá a acontecer. E, se o sistema de Hegel só era lógico em função da sua circularidade (que a dialéctica subsumia) - pois o fim seria a explicitação (e a explicação) da origem -, duvida-se que as concepções mais prospectivas (que não rompiam com o quadro do historicismo, ao contrário, por exemplo, do que acontecia com as críticas feitas, entre outros, por Herbart, Adolfo Trendelenburg e, sobretudo, por Kierkegaard e Nietzsche) fossem capazes de reconhecer o novo, isto é, algo que não se cingisse a confirmar a verdade que elas mesmas prognosticavam. É que, apesar da profissão de fé na irreversibilidade do tempo, esta insensibilidade era inerente a todo o modo necessitarista e teleológico de conceber o processo histórico, limitação que acabava por garantir uma nova face (mesmo quando encoberta) da máxima clássica: historia magistra vitae.

\section{A historia magistra vitae no horizonte historicista moderno}

Entende-se. Sem a implicação recíproca entre o alfa e o omega seria difícil credibilizar a coerência interna do percurso, pelo que Kojève tinha razão, ao concluir, na sua Introduction à la lecture de Hegel, que "a filosofia da história - e tanto mais a filosofia hegeliana, o 'sistema' - só seria possível se a história tivesse terminado". 20 Ora, se esta asserção é válida quando se acredita que a consumação já começou, também o será quando ela é situada num por-vir programado.

Em toda esta lógica, a sucessão é dita por um discurso manifesto baseado na relação causa $\rightarrow$ efeito, ou melhor, antecedente $\rightarrow$ consequente, na qual não haveria lugar para o acaso. De facto, as

20 KOJÉVE, Alexandre. Introduction à la lecture de Hegel: leçons sur la phénoménologie de l'esprit professées de 1931 à 1939 à L'École des Hautes Étudies, reunies et publiées par Raymond Queneau. Paris: Gallimard, 1947. 
filosofias da história não só contestavam a insondável intervenção de Deus - elas compaginavam-se melhor com o deísmo e com o panteísmo -, mas também rejeitavam o papel nuclear da contingência na determinação dos acontecimentos. ${ }^{21} \mathrm{Se}$, para as teorias providencialistas, aquela não passava de um disfarce da vontade divina, para os pensadores modernos (David Hume, Laplace, por exemplo), o acaso consistia numa simples designação usada para encobrir a ignorância (mas que o progresso dos conhecimentos iria colmatar), ou, então, numa manifestação fenomenológica, inteligível quando integrada no necessitarismo que comandaria a evolução global da humanidade. E mesmo um pensador como Cournot, que procurou relevar o acaso (na explicação dos fenómenos naturais e sociais), recorreu a argumentos epistemológicos (cálculo das probabilidades) e históricos para mostrar que, depois de ter partido de uma fase a ele subordinado, e de ter percorrido um período intermédio (em que a necessidade e o acaso se conciliaram), o devir estaria a entrar no seu estádio terminal, no qual a primeira subsumiria o segundo.

Bem vistas as coisas, mesmo quando o elo entre os antecedentes e consequentes se restringia ao causalismo material e eficiente (como sucedia, em boa parte, no discurso historiográfico), não se pode esquecer que, dada a índole retrospectiva e universalista das filosofias da história - elas liam o passado a partir de ideias, valores e interesses do presente -, todos aqueles eram transformados em meios, tendo em vista a realização de um fim. Neste contexto, indivíduos e povos concretos mais não seriam que instrumentos de que a lógica da história se servia para depois os aniquilar, secundarizar e ultrapassar. Dir-se-ia que elas punham o efeito como causa de suas causas, ilação que permite concluir que os seus intuitos de previsibilidade constituíam, em última análise, uma espécie de "previsão ao contrário" (Schlegel).

Deste modo, o velho preceito ciceroniano historia magistra vitae teria futuro, embora se esteja perante uma mundividência que parece situar-se nos antípodas dos seus fundamentos clássicos - a concepção cíclica do tempo e a crença no cariz ahistórico da natureza humana. Com efeito, à primeira vista, estes pressupostos não ocorreriam na modernidade, com a sua ideia de tempo irreversível. Se nada se repete, que utilidade poderiam ter as lições do passado? A resposta, na prática, não foi, porém, negativa. É que as filosofias da história, em particular as de pendor mais metafísico,

21 LIMA, Silvio. O determinismo, o acaso e a previsão na história. Coimbra: Coimbra Editora, 1958. 
acabavam por conceber o devir como uma actualização de uma potência: o seu "sujeito" ou o seu "motor". Mas como, apesar de mudar, este se manteria sempre idêntico a si mesmo, o omega não passaria da explicitação plena do princípio. Modo de dizer que, afinal, a rectileniaridade proclamada se movia nos limites de uma vivência essencialista e circular do tempo, pressuposto que, na Antiguidade, tinha justificado, embora com outros argumentos e objectivos, o magistério do passado.

Em termos epistémicos, a legitimação, quer da coerência interna das grandes explicações sobre o sentido do tempo, quer do saber historiográfico propriamente dito, relevava as relações entre antecedentes $\rightarrow$ consequentes. $\mathrm{O}$ que se entende, dado que não seria convincente explicar a sequência do eixo temporal a partir do efeito que elas mesmas procuravam demonstrar. Daí, a versão moderna e historicista da asserção ciceroniana, muitas vezes camuflada sob as vestes da previsão, pois as teorias da história dos filósofos, tal como as dos historiadores, continuarão a defender a importância de se explicar o passado, a fim de se compreender o presente e se transformar o futuro.

Em síntese: a evolução histórica estaria numa "idade" que permitia distinguir o verdadeiro "conhecimento especulativo do futuro" das previsões parcelares e particulares. Frise-se que, se Kant, na sua Antropologia em sentido pragmático (\$ 35), separou o pressentimento (praesensio) da presunção (praesagitio), também Schelling, nas várias versões $(1811,1813,1815)$ da introdução do incabado ensaio Die Weltalter, alertou para o facto de as três dimensões do tempo implicarem formas diferentes de apreensão e de linguagem: 22 o passado pode ser sabido e narrado; o presente, conhecido e exposto; mas o futuro somente pressentido [geahndet] e profetizado [geweissagt]. Cieszkowski foi mais longe, ao sustentar a necessidade de se não confundir o "deciframento do futuro" ( praesagium) com o seu saber prévio (praescientia).23 Explica-se. Em função do princípio de que só pode haver conhecimento do geral, também à historiosofia não interessava adivinhar este ou aquele aspecto particular, mas inteligir a verdadeira natureza humana, em ordem a iluminar a lei do seu progresso, quer na sua efectuação no passado, quer no que respeita às suas relações com o futuro.

22 SCHELLING, W. Las edades del mundo. Madrid: Akal, 2002.

23 CIESZKOWSKI, August von. Prolegómenos a la historiosofia. Salamanca: Ediciones Universidad de Salamanca, 2002. 
Por sua vez, as alternativas cientistas ao modo metafísico de justificar o sentido do tempo - teorizadas pelo pensamento social do século XIX - estavam eivadas de uma análoga intenção de presciência, e tinham a vantagem de dar uma ainda maior visibilidade à "vontade de poder" da episteme moderna, já sintetizada por Francis Bacon no célebre aforismo: saber para prever, prever para prover. Montesquieu, em De l'Esprit des lois, não andou longe deste objectivo, mormente quando recorreu a modelos físicos e ao causalismo usado nas ciências da natureza para tentar explicar, em termos deterministas, a relação (a lei) entre os fenómenos sociais, visando a previsão. Todavia, antes de A. Comte, foi Condorcet quem melhor expressou o intento de se unificar a metodologia das ciências naturais com as das ciências sociais, condição fundamental para que estas conquistassem a previsibilidade que havia feito o prestígio das primeiras. É que, segundo ele, "se o homem pode predizer, com segurança quase total, os fenómenos cujas leis conhece; se, mesmo quando as desconhece, pode, com base na experiência do passado, prever, com uma grande probabilidade, os acontecimentos do futuro; porquê encarar como uma empresa quimérica traçar, com alguma verosimilhança, o quadro dos destinos futuros da espécie humana, segundo os resultados da sua história? O único fundamento da crença nas ciências naturais é a ideia de que as leis gerais, conhecidas ou não, que regem os fenómenos do universo, são necessárias e constantes; e por que razão este princípio havia de ser menos verdadeiro para o desenvolvimento das faculdades intelectuais e morais do homem do que para as outras operações da natureza?". 24

A busca dos mesmos "fundamentos de crença" pode ser encontrada nas várias propostas que, no século XIX, darão vida aos imaginários de inspiração socialista, assim como às múltiplas tentativas para justificar a emergência da ciência social: a "fisiologia social" em Saint-Simon; a "sociologia" em Comte; o "materialismo histórico" em Marx. É certo que estas propostas se distinguiam entre si, tanto nos seus fundamentos como nos seus objectivos sociais, e as que proclamavam um cariz mais cientista acusavam as restantes de serem metafísicas ou utópicas. Todavia, a todas é aplicável o programa formulado por Buchez: fazer da história uma ciência, apta - em analogia, aliás, com a capacidade das filosofias da história - para prever o futuro social da espécie humana, na sua

24 CONDORCET. Esquisse d'un tableau historique des progrès de l'esprit humain. Paris: Boivin et Editeurs, 1933. 
livre actividade. ${ }^{25} \mathrm{E}$ o desiderato de A. Comte - numa versão mais conservadora - é semelhante, pois tentou demonstrar que a sociologia tinha por finalidade última concretizar a máxima baconiana. Maneira de sustentar que a vocação da nova ciência social, legitimada através da célebre lei dos três estados, desaguaria em técnica. E a "engenharia social" destes projectos, tanto podia servir para reproduzir o mundo histórico tal qual ele existia (era essa a intenção de Comte), como para criticá-lo, para o revolucionar. Deste modo, é lícito concluir que o optimismo moderno se baseava num optimismo epistemológico de cariz prometeico e fáustico. O que dá lógica ao facto de a sua proclamada presciência não se ter limitado ao papel de um ideal regulador, pois também conduziu a um necessitarismo que só não se confundia com o determinismo absoluto porque apelava à praxis, desde que mediada pelo saber.

Como salientou Rosenzweig, 26 a ideia de causalidade (invocada, tanto pelas filosofias da história, como pela historiografia) só podia ser convincente e operativa se narrasse o passado como quem desenrola um fio temporal contínuo, em que o antes (a causa) determina o depois (o efeito), ordenação que, confessadamente ou não, escondia a teleologia que a estruturava, como se o futuro fosse só um efeito do passado, sendo impossível o contrário. E o optimismo antropológico e epistemológico, que dava seiva ao novo ideal de ciência, alargou-se, no século XVIII, à racionalidade que o tempo histórico estaria a explicitar. Já não se tratava de invocar causas externas: a velha "providência" transmudou-se em "lei", ou em "tendência objectiva", e o princípio da razão suficiente neste outro: todo o real é racional e todo o racional é real. E, se foi a linguagem filosófico-metafísica que, pioneira e sistemicamente, melhor tematizou este último, a verdade é que ele continuará ínsito às diversas traduções cientistas que, sobretudo após as primeiras décadas do século XIX, irão perseguir objectivos análogos.

O facto desta visão se ter tornado dominante (e se ter popularizado através das mais diversas traduções ideológicas) não deve fazer olvidar, porém, que tal hegemonia recebeu várias críticas. Em primeiro lugar, a da reacção romântica contra os seus excessos, atitude que se expressou numa maior valorização da subjectividade, da concretude histórica (Volksgeist), da vontade e sentimento, da organicidade, bem como numa representação mais dramática e trágica do devir humano, enxertando na ideia de progresso a possibilidade da sua degenerescência e decadência. Não por acaso,

25 BUCHEZ, Ph. J. Introduction à la science de l'histoire. Paris: Guillaumin, 1842. v. 1.

26 ROSENWZEIG, Franz. L'étoile de la redemption. Paris: Esprit, 1982. 
contra ou corrigindo Condorcet, descobriu-se Vico (Edgar Quinet traduziu a Ciência Nova para francês, enquanto Michelet se encarregou de Herder) e a sua periodização da história segundo o ritmo dos corsi e dos ricorsi.

Esta tendência crítica recebeu um desenvolvimento ainda mais radical em pensadores como Schopenhauer e Eduardo de Hartmann, e no anti-historicismo de Nietszche. Com isso, cresceu uma orientação de teor mais pessimista, que levará alguns até às portas do niilismo. Mas outros tentaram conciliar a herança iluminista com este fundo reactivo, pondo em diálogo as duas posições. Outros, ainda, nas suas críticas ao necessitarismo e ao determinismo, mostrar-se-ão mais abertos à valorização do papel do acaso (Cournot), ou à perspectiva probabilística dos fenómenos naturais e sociais.

De qualquer modo, a ideia de tempo histórico fundamentada pelas grande filosofias do século XVIII e XIX subsumia estas prevenções, talvez porque o seu necessitarismo, as suas pretensões à apreensão da totalidade e o seu optimismo racionalista e prometeico vinham ao encontro das expectativas de uma civilização que estava num processo acelerado de industrialização, urbanização e massificação.

Ora, se o necessitarismo (e, em alguns casos, o determinismo) era comum à grande maioria das teorias da história, pergunta-se: nesse rio inexorável e (aparentemente) irreversível, movido por um agente ou "motor" colectivo, qual o papel dos indivíduos no condicionamento do seu percurso? Responder exige que se sopese o modo como foram negados ou secundarizados, não só o acaso, mas também a acção dos sujeitos que, pelas suas obras, mais pareciam ter determinado o seu itinerário.

\section{A dimensão épico-trágica do "grande homem"}

É indiscutível que as novas teorias sobre o sentido universal da história pretendiam fazer aumentar o poder do homem sobre a sociedade (que é sempre poder de alguns homens sobre outros homens), desiderato que ilumina o papel que, implícita ou explicitamente, a si mesmo se atribuíam os que se proclamavam como reveladores da verdade, e cuja encarnação suprema se deu na figura do "grande homem" e, em particular, na do "revolucionário". Com efeito, em nenhuma outra experiência a convicção de que o homem é o único construtor da história parecia ser fruto de uma encarnação individualizada. É que, nas revoluções, momentos de 
aceleração do tempo, os "revolucionários" irrompem como "grandes homens", epifania que parece mostrar que são eles os grandes artífices da ruptura. Porém, não se deve esquecer que, para as filosofias da história, eles se limitam a dar voz a uma existência colectiva, pelo que não passariam de emanações subjectivas da consciência de um povo, de uma nação, de uma classe, da humanidade, do espírito universal. Ora, se até os protagonistas mais evidentes são reduzidos a meros instrumentos da razão histórica, como conciliar esta contradição, afinal uma das faces da que existia entre o universal e o particular, a necessidade e a liberdade, a dimensão colectiva e abstracta do devir e a acção dos indivíduos?

A resposta teve várias versões, mas todas elas, directa ou indirectamente, remetem para Hegel, que reconheceu o papel do acaso (mas para o pôr ao serviço da "astúcia da razão") e o dos "grandes homens", embora para os caracterizar como os indivíduos que, melhor do que os seus contemporâneos, e mesmo sem o pleno controlo sobre os efeitos das suas acções, souberam explicitar e pôr em prática as necessidades objectivas do espírito do tempo (Zeitgeist). Para o filósofo alemão, "tais indivíduos não tinham consciência da Ideia geral que desdobravam enquanto perseguiam os objectivos deles... Mas, ao mesmo tempo, eram homens de pensamento, com apreensão das necessidades da época - o que estava maduro para a colheita. Esta era a verdade autêntica para a sua época e para o seu mundo: a forma que devia seguir-se, por assim dizer, e que já estava engendrada no ventre do tempo... As individualidades histórico-mundiais - os heróis de uma época - devem portanto ser reconhecidos como os seus filhos de mais ampla visão: as suas acções, as suas palavras, são as melhores desse momento". 27

Sob o impacte desta definição, virá a fixar-se, nas décadas seguintes, a teoria do "grande homem" como o medium por excelência da ideia geral de história, não obstante - e numa recuperação dos ensinamentos de Herder - ele ser cada vez mais particularizado como um mero revelador do carácter específico do seu povo, do seu tempo, e, para algumas correntes que foram ganhando força, da sua raça. Portanto, nele se encontraria concentrado, personificado e prototipificado, tanto o geral como o particular, conquanto numa consubstanciação que podia gerar a ilusão de que a história era um produto da subjectividade e da liberdade absolutas do indivíduo. Contra esta ilusão, as filosofias da história dominantes,

27 HEGEL, G.W.F. La raison dans l'histoire. Paris: UGE, 1965; GARDINER. Patrick. Teorias de história. Lisboa: Gradiva, 1984. 
com o seu necessitarismo imanente, procuraram demonstrar que só dentro do todo evoluente o papel que lhes tinha sido atribuído ganhava verdadeira luz, pois ele arrastava consigo, em simultâneo, o passado e o futuro: o passado, dado que já antes se teria pressentido, como espera, a sua iminente emergência; o futuro, porque, quando o finalismo histórico o obrigou a sair de cena (o desfecho obrigatório para todos os indivíduos e, por analogia, para todos os povos), os efeitos da sua actividade perdurarão como exempla virtutis, isto é, como fama, ${ }^{28}$ ou como condenação.

Este ideal - que o historiador Justus Moeser já havia antevisto - foi acolhido por outros discípulos de Hegel (Victor Cousin) e, miscegenado, sob a influência de Herder, com contributos de românticos como Gorim, Goerres, Niebhur, entre outros, tornou-se numa caracterização dominante. Porém, a sua mais acabada sistematização - ainda que com fundamentos que pretendiam ser anti-metafísicos - encontra-se no pensamento de Comte e de seus seguidores. Aqui, descontados os sofismas no que toca à idolatria do novo Deus - a humanidade -, ele é equacionado em termos ainda mais deterministas. Mas, apesar das diferenças, ter-se-á de aceitar que todas estas concepções o caracterizaram como uma espécie de sujeito não subjectivo, recusando dar-lhe uma autosuficiência verdadeiramente criadora, condição, aliás, só reivindicada por algum romantismo mais solipsista ou radical. Assim, ao invés da tese voluntarista e individualista de Carlyle, ${ }^{29}$ ele seria, não tanto um agente, mas mais um agido, ou melhor, uma personagem-símbolo do espírito colectivo. ${ }^{30}$ Por palavras de Alexandre Herculano - o primeiro grande representante da ideia no pensamento português, logo seguido por Oliveira Martins -, "o indivíduo que vai à frente da sua época é a ideia predominante dela, encarnada no homem", pelo que os génios são, tão-somente, "o verbo da ideia, são os intérpretes do género humano - e mais nada". 31

Esta leitura parece contraditar o apelo à "fabricação" do tempo histórico contido no optimismo que alentava a mundividência moderna, ilação que, todavia, deve ser completada por esta outra: o convencimento da sua verdade compelia à acção, certeza que era reforçada quando a teoria (ou o programa, ou o plano) era acreditada como sendo um ditame científico (como o será nas várias sociologias e, sobretudo, nos vários marxismos). E seria nesta experi-

28 CIESZKOWSKI, op. cit.

29 CARLYLE, Tomás. Los héroes. El culto de los héroes y lo heroico en la historia. México: Porruá, 2000.

30 LIMA, op. cit.

31 HERCULANO, Alexandre. Opúsculos. Lisboa: Presença, 1986. v. 5. 
ência, alimentada pela crença na translucidez da razão histórica, que a liberdade se fundiria com a necessidade. Assim sendo, a situação do "grande homem" era paradoxal: como mediador, ele actualizava os mais avançados - mesmo que, até ele e para ele estivessem escondidos - imperativos da história, mas estes acabavam por ultrapassá-lo, dada a índole objectiva, universal, colectiva e futurante do devir. Devido ao seu papel mediador, ele não sabia - como mostravam os casos de César e de Napoleão, invocados por Hegel - que os efeitos da sua própria praxis também o estavam a cegar, obscuridade que, para ser alumiada, exigia, como paga, um destino trágico para a sua aventura épica no grande teatro do mundo. Daí, a infelicidade do remate da sua existência: ou morrem novos, ou são assassinados, ou são presos, ou são incompreendidos. A epicidade do momento de apogeu mais não é do que o primeiro acto da decadência futura.

\section{III \\ O fim do fim da história}

Perante o exposto, verifica-se que a promessa iluminista dos vários projectos filosóficos transportava consigo a ideia de fim da história, a qual, ou se saldava numa previsão em que este é representado como uma espécie de paragem, para além da qual se entraria na pós-história, período indefinido, sem negatividade e sem progresso (na acepção substantiva como o século XVIII o definiu); ou aparecia como um acabamento que consumaria o devir como "reino da liberdade"; ou surgia, ainda, como um ideal regulador e assimptótico, nunca plenamente realizável, mas que propulsava a humanidade para o futuro, ao mesmo tempo que ajudava a criticar as injustiças do presente, dando continuidade à vocação críticoutópica do seu momento inaugural.

De qualquer maneira, postular a existência de uma finalidade e, portanto, de um fim, mesmo quando se fala em nome da ciência (como em Marx e em Comte), requeria a pressuposição de um fundamento metafísico que nunca se confundia com a fenomenologia do devir. E, se as filosofias da história, depois de Spengler e Toynbee, entraram em perda de prestígio, essa desvalia foi consequência das alterações ocorridas no pensamento contemporâneo, sejam elas de cunho epistemológico (o neokantismo), de cariz existencial (Heidegger e seus seguidores), ou vindas da filosofia analítica anglo-saxónica, ou, ainda, das recentes críticas lançadas pelo camartelo posmodernista, que as acusa de serem metanarrativas 
totalizadoras e finalísticas, e de inspirarem práticas que desmentem as suas promessas, feitas em nome da verdade.

Mais especificamente, a desconstrução pós-moderna rejeitaas (correctamente, na nossa maneira de ver) pelas seguintes razões fundamentais: por se imporem como normas externas, organizadoras dos acontecimentos e das acções humanas; por se estruturarem como metanarrativas teleológicas, ao colocarem em acção uma meta, postulada aprioristicamente e, por conseguinte, situada à margem do próprio devir; e por serem, em última análise, representações metafísicas, dado que, nelas, a história real fica condenada a ser a mera explicitação temporal de uma essência simultaneamente intra e supra-histórica, pois só se realizará no fim da história. 32

Entende-se que, onde as filosofias da história invocaram um fundamento para o devir, os críticos tenham destacado a autosuficiência das acções humanas e dos acontecimentos, com a conseqüente valorização do papel dos indivíduos e do acaso, e com a inevitável depreciação de conceitos como totalidade, transição, determinação, finalidade, estrutura, etc. A história deixa de ser concebida como um processo ontologicamente dotado de sentido, ilação que arrasta consigo todas as visões evolutivas, continuístas e progressivas, julgadas como sucedâneas de expectativas religiosas e contraditadas pela prática histórico-social, tanto mais que esta estará a negar o sonho emancipatório que elas despertaram e que foi a razão última do seu sucesso ideológico.

Como alternativa, enfatiza-se a fragmentação, a vida quotidiana, a dimensão pequena dos acontecimentos, e são igualmente rejeitadas as explicações por causalidade eficiente (ou final), a favor da apreensão subjectiva dos comportamentos subjectivos, logo, da compreensão; o que conduz à recusa do estatuto de verdade de inspiração cientista e racionalista. Isto é, e como afirma G. Vattimo, se a epistemologia moderna fez radicar a convicção de que os discursos são mensuráveis e traduzíveis entre si, e defendeu que o fundamento da sua verdade consistia em traduzi-los numa linguagem básica, que se acreditava reflectir os factos, a nova hermenêutica não aceita a existência de tal linguagem artificial, relevando, como alternativa fundante, a abertura à compreensão da linguagem viva do outro. ${ }^{33}$

32 CABRERA ACOSTA, Miguel Ángel. La história y las teorias del fin de la historia. In: BARROS, Carlos (ed.). Historia a debate. T. 1. Santiago de Compostela: Historia a Debate, 1995.

33 VATTIMO, Gianni. O fim da modernidade: niilismo e hermenêutica na cultura pósmoderna. Lisboa: Presença, 1987; CABRERA ACOSTA, op. cit. 
Denuncia-se, ainda, o facto de a coerência interna das metanarrativas ser construída a partir da ideia apriorística de finalidade (e de fim), bem como do lugar eleito para a concretização da história universal: a Europa (ou melhor, o Ocidente). E, contra este eurocentrismo - que terá sido legitimador das práticas de dominação colonial, imperialista e racista -, advoga-se o cariz não hierarquizável do devir e procura-se demonstrar, ao invés da pretensa vocação universalista e homogeneizadora da história, o modo policêntrico como ela se processa. Em síntese: o pós-modernismo propõe-se liquidar os "quatro pecados capitais" da modernidade, a saber: o reducionismo, o funcionalismo, o essencialismo e o universalismo. ${ }^{34}$

Esta atitude crítica pôs a descoberto convencimentos e optimismos que não são consentidos por qualquer leitura que esteja mais atenta à riqueza multímoda dos acontecimentos do que à coerência interna das totalidades explicativas. No entanto, considerar-se - em termos emblemáticos, é certo - que a credibilidade dos pressupostos da modernidade morreu em Auschwitz, será não relevar duas coisas. Em primeiro lugar, a chamada modernidade, mesmo na sua expressão como filosofia da história, não foi uniforme, nem redutível à sua componente iluminista, nem a leituras dualistas (por exemplo, as que separam, dicotomicamente, o Iluminismo de movimentos como o Sturm und Drang). A par e contra o Iluminismo, manifestaram-se ideias, sentimentos e valores igualmente modernos e comummente designados por românticos. E estes não deixaram de ser modernos ao reivindicarem a subjectividade, a insolubilidade das antíteses, a dimensão contraditória do eu, o particular e a diferença, ao porem limites ao progresso indefinido, ao defenderem o sentimento, a interacção e a experiência, ao recusarem a cesura entre o homem e a natureza, ao assinalarem (contra os exageros do cosmopolitismo) a índole histórica dos povos e das nações - tradução particular da tensão moderna entre memória e expectativas, atitude que só nas suas interpretações regressivas é passadista. Por sua vez, importa não esquecer que a consciência ético-crítica em relação a acontecimentos como Auschwitz ou o Goulag (e a todos os fundamentalismos) põe em prática juízos que não são estranhos ao melhor da herança da modernidade.

34 PORTER, Mark. Cultural history and postmodernity. New York: Columbia University Press, 1997. 
Poder-se-á perguntar, por outro lado, se conceitos como descontinuidade, fragmentação, policentrismo, acaso, subjectividade, compreensão e outras, poderão, só por si, ser pensados e aplicados a um mundo crescentemente relacional e comunicacional (Habermas), sem a sua geminação com os de universalidade, continuidade, totalidade, centralidade, necessidade, objectividade. E não basta dizer - numa espécie de interiorização da culpa histórica - que o universalismo subjacente às filosofias da história só serviu de capa encobridora da visão eurocêntrica e dos seus projectos de dominação de outros povos. Se é certo que esta denúncia tem toda a pertinência, terão de ser equacionados, igualmente, os efeitos decorrentes da outra face destes valores, já que será precisamente a partir da sua raiz crítica e das suas promessas de universalismo não cumpridas (exemplo: os direitos humanos) que os dominados encontraram armas para contestarem os dominadores e para fundamentarem a sua própria identidade. Ora, cair em posições dualísticas - como se encontram em algumas teses sobre o orientalismo (Edward Said) -, será correr o risco de somente se continuar a ver um dos ângulos do processo histórico real, ficando-se sem capacidade para analisar influências, reciprocidades, relações de dominação (colonialismo, exploração social, imperialismo político, violência, etc.), bem como as contradições internas existentes no interior de cada um dos pólos; e nunca se perceberá que aquilo que serve para oprimir também pode ser utilizado como instrumento libertador.

É que, se a história concreta mostra que todas as épocas e situações são iguais perante Deus (Herder, Ranke), em termos de poder, umas estarão mais próximas Dele do que outras. E, se a tradução ontológica e totalizadora da ideia de sentido histórico é insustentável, em termos hermenêuticos, a compreensão introdula, pelo menos na sua dimensão dialógica e inter-subjectiva. Mas importa ter presente que reduzir a sua lisibilidade à compreensão será confinar as acções humanas à intencionalidade subjectiva; o que leva a esquecer os efeitos involuntários das acções, assim como a condicionalidade objectiva que decorre da integração dos indivíduos em situações espaço-temporais concretas. Significa isto que, em termos epistemológicos, a compreensão terá de ser acasalada com a explicação, combinatória cujo grau de aplicabilidade só pode ser ditado pela problemática que interroga os sinais deixados pela acção humana.

Por outro lado, a invalidação das ideias construídas durante a modernidade e dos seus prognósticos não pode negar esta evidência: mesmo que não se aceite a existência de uma direcção para a 
história, esta é toda feita de mudança, característica que as sociedades contemporâneas têm acelerado mais do que quaisquer outras. ${ }^{35} \mathrm{E}$ a tentativa de convencer que já se vive uma época depois da história acaba por pressupor uma crença análoga à que ela pretende extinguir: a aceitação de uma sucessão qualitativa na ordem do tempo. Pode mesmo defender-se que a sua crítica recorre a duas posições típicas das filosofias da história da modernidade: um juízo negativo perante o presente, à luz do qual, como nas visões cíclicas e judaico-cristãs, este continua a ser visto como um período de transição ou de decadência; e a invocação de um saber que também almeja decretar, ainda que por via negativa, o (não) sentido do devir, embora escudando-se na crítica às filosofias do fim da história. ${ }^{36}$ Modo de pensar que certas teses pós-modernas representam uma nova versão da ideia de culminação, pois o tempo, destituído de suportes potenciais que explicitavam a sua finalidade, mais não será que a permanente reactualização de um eterno presente. ${ }^{37}$

A óptica das filosofias do fim da história e a das críticas que a pós-modernidade lhes lançou acabam, assim, por se tocar, conquanto por caminhos diferentes. Como defendeu Jérôme Baschet, "o presente perpétuo é, talvez, precisamente, o pólo de atracção comum que influencia um e outro, conduzindo ao desaparecimento do horizonte das expectativas e a uma imobilização no presente, idealizado num caso, e desenganado no outro". ${ }^{38} \mathrm{E}$ a apologética destes "legionários do instante presente" (Nietzsche) só pode suscitar uma espécie de idolatria do real, tal qual se julga que ele é, ${ }^{39}$ esquecendo-se que se está a assistir, não ao fim da história, mas, tão-só, ao fim das filosofias do fim da história.

\section{A sempre iminente irrupção do novo}

De facto, se o investimento historicista (em qualquer das suas modalidades) constituía prática adequada a uma concepção acumulativa, evolutiva e continuística do tempo, hoje, a situação pa-

35 BAIER, Lothar. Pas le temps! Traité sur l'accélaration. Arles: Actes du Sud, 2002.

36 RAULET, G. (pres.). Aufklärung. Les lumières allemandes. Paris: Flammarion, 1995.

7 CABRERA ACOSTA, op. cit.

38 BASCHET, Jerôme. L'histoire face au présent perpetuel. Quelques remarques sur la relation passe/futur. In: HARTOG, François, REVEL, Jacques (org.). Les usages politiques du passé. Paris: Éditions de l' École des Hautes Études en Sciences Sociales, 2001.

39 ANDERSON, Perry. The ends of history. In: ANDERSON, Perry. A zone of engagement. London: Verso/NLB, 1992; BASCHET, op. cit. 
rece ser diferente. As mudanças sociais que ocorreram no mundo e a contestação feita tanto às filosofias da história (no último século, praticamente reduzidas às suas imediatas traduções ideológicas, uma das chaves do êxito de Fukuyama), como às suas ideias norteadoras (perfectibilidade, evolução, continuísmo, progresso, previsibilidade), instalaram um sentimento de descontinuidade, pluralidade, variação e não sentido em relação ao tempo (psicológico e histórico). E a diminuição da sua vivência como presente real (complexo e tensional) tem provocado, em simultâneo, a "morte" da pretensão de se domesticar e programar o futuro, diluída na euforia do viver em tempo real. ${ }^{40} \mathrm{Com}$ isso, caiu-se num culto do presente, ${ }^{41}$ como se este fosse uma incessante eternidade, sem abertura para o passado e para o porvir, mnemotropismo que exprime a perda de referências e o decréscimo da adesão dos indivíduos a identidades holísticas externas. Atitude que parece ter como uma das suas causas o esgotamento das "filiações escatológicas", ou melhor, das grandes memórias e narrativas organizadoras e reprodu-toras do elo social (família, igreja, partido, sindicato, nação, humanidade), e conferidoras de uma direcção para a história. Daí que a ideia de futuro (como a de futuro do passado) tenha enfraquecido, ${ }^{42}$ como se não mais existisse qualquer distância entre 0 passado e o presente, ou melhor, entre o campo de experiência e o horizonte de expectativas. ${ }^{43} \mathrm{O}$ que se pergunta, porém, é se uma dada situação histórica, que tende a banalizar a ideia de novo, confundindo-a com o efémero e o vazio, pode estancar de vez a índole desejante do modo de ser do homem, insatisfação que o incita à criação do que ainda não é. Ora, como salienta Santo Agostinho, o homem é "bestia cupidissima rerum novarum, 'animal avidíssimo de coisas novas', tanto no sentido do 'mais', como no sentido do 'de outro modo'." 44

O surgimento do novo é fulguração que brota da tensão entre herança e expectativa, impulso individual (e portanto colectivo) que desmente profecias, prognoses e previsões, mesmo quando parcialmente as confirma. A história não morre, como não se extingue a necessidade de a interrogar; o que vai definhando são as

40 RICOEUR, Paul. La lectura del tiempo pasado. Memoria y olvido. Madrid: Ediciones de la Universidad Autónoma de Madrid, 1998.

41 HARTOG, François.Temps et histoire. Comment écrire l'histoire de France. Annales HSS, n. 5, 1995.

42 BASCHET, op. cit.

43 KOSELLECK, op. cit.; CATROGA, op. cit.

44 Santo Agostinho apud LAIN ENTRALGO, Pedro. O que é o homem? Lisboa: Notícias, 2002. 
suas representações concretas, socialmente condicionadas, incluindo a omnisciência do prognóstico sobre o seu ponto omega. E o grande pecado das filosofias da história, bem como dos seus epifenómenos contemporâneos, residiu na dificuldade de se abrirem ao futuro-futuro como o fizeram em relação ao novo com que se auto-legitimaram perante o seu próprio passado. Com efeito, é indiscutível que a modernidade (e, com ela, a consciência histórica que a justificava) se consolidou à volta de uma ideia nuclear: a representação do tempo histórico como um itinerário, no qual o presente foi valorado como sendo qualitativamente superior ao passado, hierarquia que colocava, explicitamente ou não, o novo no cerne da sua legitimação. Todavia, à luz da sua ideia evolutiva, acumulativa e teleológica, as filosofias da história procuraram convencer que, após o anúncio da verdade, o futuro seria o cumprimento de um plano ou de um programa já por elas previsto. Daí a pergunta: poder-á acolher a experiência do novo, quando a história é apresentada como um encadeamento necessário, no qual, em última análise, a ideia apriorística de fim se encontra insinuada desde a origem?

Logo em 1818, Wilhelm Humboldt respondeu que não. No seu ensaio Betrachtungen über die bewegenden Ursachen in der Weltgeschichte, (Reflexões sobre as causas motoras na história universal), critica, na linha de Herder, os excessos do optimismo iluminista, aconselhando a que se distinga o curso mecânico da história, da irrupção repentina do novo, entendido como surgimento de gerações e revoluções, e como a característica constituinte da própria historicidade. 45 Por sua vez, a contestação do historicismo feita por Nietzsche em nome da vida, assim como a de Walter Benjamin, suplicando para que, em cada momento que tece o presente, se esteja atento e receptivo, quer às vozes do passado, quer à visita do anjo do futuro, lançaram questões que inquietam e que, por isso, contribuem para se evitar o dogmatismo, que os saberes prognósticos tendem a provocar. Separar o futuro do seu determinismo ou necessitarismo teleológico será aceitar a "messianidade", sem que, com isso, se tenha de cair no messianismo (Derrida). Como imagem, poder-se-á mesmo afirmar que a experiência do novo não pode ser confundida, sequer, com a surpresa que se sente quando a pessoa (ou o acontecimento) que se espera chega mais cedo: ela deve ser franqueamento da porta a quem bate, mesmo que inesperado e desconhecido. E a previsão, se impele à praxis para que se cumpra o que se vaticina (ficando por saber, quando

45 HUMBOLDT, Wilhelm von. Escritos de filosofia de la historia. Madrid: Tecnos, 1997. 
se acerta, se isso derivou da justeza do prognóstico, ou do voluntarismo que ele desperta para o tornar verdadeiro), também provoca surdez e cegueira em relação a tudo o que a não comprova. Daí, a dimensão fechada e vocacionalmente totalitária das "engenharias sociais" prognósticas e o esquecimento de que o futuro está sempre a realizar-se, numa tensão com o incessante renovamento do recordado.

A recepção do novo não pode significar, porém, uma hospitalidade acrítica, pois ele vem morar numa terra já habitada por homens com racionalidade ética e com memória; e é pela comparação, logo suscitada pela pré-compreensão, que a densidade do "aumento de ser" que ele oferece deve começar a ser avaliada. Caso contrário, cair-se-á na reificação da novidade, como se o tempo fosse, tão-só, um infinito somatório de momentos sem passado e sem futuro entre si. E se, como bem ensinou Ernst Bloch, só quem espera o inesperado o poderá encontrar, tal atitude, em vez de passiva, tem de ser activa; deve-se agir para criar, mesmo sabendo-se, de lição colhida nos desmentidos da própria história, que a confirmação da expectativa é, tão-só, o selo da carta que, dentro, também traz o anúncio do seu fracasso. Como, algures, escreveu Paul Valéry, "prevejo, logo, engano-me". Só neste risco que é inerente à afirmação da vida - o futuro continuará aberto. Conseqüentemente, a história só será mestra da vida se, em primeiro lugar, a vida for mestra da história. 